\title{
Spotlight on triptorelin in the treatment of premenopausal women with early-stage breast cancer
}

This article was published in the following Dove Press journal:

Breast Cancer - Targets and Therapy

\section{Marta Venturelli' \\ Giorgia Guaitoli' \\ Claudia Omarini' \\ Luca Moscetti}

'Division of Medical Oncology, Department of Medical and Surgical Sciences for Children \& Adults, University Hospital of Modena, Modena, Italy; ${ }^{2}$ Division of Medical Oncology, Department of Oncology and Hematology, Azienda Ospedaliero Universitaria Policlinico di Modena, Modena, Italy
Correspondence: Luca Moscetti Medical Oncology, Department of Oncology and Hematology, Azienda Ospedaliero Universitaria Policlinico di Modena, Via del Pozzo 7I, 4I I 24 Modena, Italy

Tel +3959422 3244

Fax +3959 4222647

Email moscetti.luca@policlinico.mo.it

\begin{abstract}
Endocrine treatment represents the cornerstone of endocrine-sensitive premenopausal early breast cancer. The estrogen blockade plays a leading role in the therapeutic management of hormone receptor-positive breast cancer together with surgery, radiotherapy, and selective antiestrogen treatments. For several years, selective estrogen receptor modulators, such as tamoxifen, have represented the mainstay of therapy. The role of amenorrhea has been extensively elucidated in the past year: the benefit observed with chemotherapy-induced amenorrhea has strengthened its therapeutic role. Luteinizing hormone-releasing hormone (LHRH) has been introduced in oncology practice to induce amenorrhea in order to increase the advantage obtained from endocrine treatment. Triptorelin is one of the most widely used LHRH analogs currently available in clinical practice. It was recently investigated in two major clinical trials that studied the role of complete estrogen blockade in the premenopausal setting. Both showed the clinical benefit due to ovarian suppression treatment, primarily in high-risk patients. Furthermore, triptorelin and other LHRH analogs have recently been investigated in the attempt to preserve the ovarian function in young patients. The medical treatment of early breast cancer is always evolving in the effort to search for safe and efficacious treatments. The role of LHRH analogs is actually well recognized as contributing to the improvement of the medical treatment of premenopausal women with early breast cancer.
\end{abstract}

Keywords: adjuvant, hormone therapy, LHRH, amenorrhea

\section{Introduction}

Luteinizing hormone-releasing hormone (LHRH) is a decapeptide hypo-physiotropic hormone produced by the hypothalamic neurons, which plays a central role in the endocrine regulation and the control of reproductive functions. It is secreted, in a pulsatile way, from the median eminence into the portal vein system, reaching the anterior pituitary gland inducing the release of the following two gonadotropin hormones: follicle-stimulating hormone (FSH) and luteinizing hormone (LH). The role of FSH and LH is crucial in the gametogenesis and steroid production. The gonadal steroids regulate the secretion of LHRH through the binding to specific receptors expressed on the hypothalamic neuronal cells and pituitary gland. ${ }^{1}$ Since its discovery, LHRH has been studied for its potential activity in controlling the growth of endocrine sensitive cancer cells such as prostate, ovarian, endometrial, and breast cancers. The following two types of LHRH analogs have been developed: the LHRH agonists and the LHRH antagonists. LHRH agonists were introduced initially in the treatment of endocrinesensitive cancers, such as prostate and premenopausal breast cancers. They represent 
the cornerstone of current endocrine treatments for both early and advanced disease. LHRH antagonists were developed some years later; their main application is in the management of prostate cancer.

\section{LHRH agonists: biology and antitumoral effect}

The LHRH agonists used in daily clinical practice are as follows: goserelin, tryptorelin, leuprorelide, and buserelin. They are decapeptides with an arginine in position 8 (Arg8) that is essential for the affinity to the mammalian receptor. The introduction of hydrophobic groups on the sixth amino acid further increases this bond with a major resistance to the enzymatic degradation. ${ }^{2}$ The LHRH analogs operate as anticancer agents suppressing the pituitary gonadal functions, determining the fall of gonadal steroids levels, and reducing their mitogenic activity. Furthermore, it seems that LHRH analogs could have a direct antitumoral effect. In fact, the LHRH receptors are present in the cancer cells. The mRNA encoding for these receptors is similar to the pituitary receptors. An inhibition in cellular tumor growth has been observed in breast cancer. ${ }^{3-10}$ Physiologically, in pituitary gland, the gonadotropin receptor $(\mathrm{GnRH})$ signaling is mediated through the G-protein $\alpha_{\mathrm{q}}$. These proteins conduct the subsequent activation of phopholipase $\mathrm{C}$ (PLC) that catalyzes the hydrolysis of membrane phospholipids generating the liberation of intracellular $\mathrm{Ca}^{2+}{ }^{11,12}$

The antiproliferative effect of LHRH analogs seems to be related to the signal transduction pathways involving the growth factor-induced mitogenic signaling, as the activity of MAPK and the c-fos expression. The GnRH receptors evident in the tumor activate phosphotyrosine phosphatase (PTP), resulting in the inhibition of mitogenic signal transduction and the reduction of cell proliferation. ${ }^{13}$ Normally, estrogen induces gene transcription through nuclear receptor activation binding to the promoter of sensitive genes, but other unconventional transcriptional pathways could be involved as follows: steroidogenic factor-1 (SF-1) ${ }^{14}$ specific factor-1 (Sp1), ${ }^{15-17}$ nuclear factor-Y (42), and activator protein-1 (AP-1). ${ }^{18,19}$ Furthermore, the MAPK pathway may be involved in a nongenomic stimulus, inducing the activation of proto-oncogene $c$-fos. ${ }^{20}$

\section{LHRH analogs and first evidence in early breast cancer}

Chemical castration is the main reason for the clinical use of LHRH analogs in the endocrine-sensitive early breast cancer.
Since the first evidence of efficacy of ovarian ablation in the treatment of breast cancer, ${ }^{21}$ various methods were explored to induce the ovarian suppression. ${ }^{22}$ Evidence from initial trials in metastatic breast cancer patients allowed the introduction of the possible use in the adjuvant setting for the endocrinesensitive early breast cancer.

In clinical practice, the LHRH analogs have been added to the standard tamoxifen therapy due to the increased suppression of circulating estrogens achieved with the combination in previous studies. ${ }^{23-26}$ The question about the role of LHRH being added to chemotherapy, or compared to chemotherapy, has been evaluated in five randomized studies and a metaanalysis. These trials showed that the addition of LHRH to chemotherapy improves the outcome, but none of these trials contains an arm with tamoxifene alone or evaluates the estradiol (E2) levels after chemotherapy (Table 1). ${ }^{27-33}$ The Early Breast Cancer Trialists' Collaborative Group (EBCTG) pointed out the value of ovarian suppression showing an improvement in recurrence-free interval and survival, across 2102 women treated in the clinical trials. ${ }^{34-36}$ In 2001, the EBCTG published an overview of the available randomized trials involving LHRH analogs in the premenopausal early breast cancer setting conducted before 1990s. This analysis pointed out the value of the addition of LHRH analogs to the standard hormone therapy, represented by tamoxifen. ${ }^{37}$ Triptorelin was the LHRH analog used in one of the four studies examined in the review. In 2005, EBCTG produced a new overview in which LHRH analogs added to chemotherapy was the more advantageous possible therapeutic option, especially for patients younger than 40 years. ${ }^{37} \mathrm{~A}$ meta-analysis of individual patient data, from 16 randomized adjuvant trials, has been conducted by Cuzick. Patient data of 11,906 women (9022 women were hormone receptor positive $[\mathrm{HR}+]$ ) was included in the review. The addition of an LHRH agonist to tamoxifen, chemotherapy, or both significantly reduced the risk of recurrence, the death after recurrence, and any death. In women with $\mathrm{HR}+$ breast cancer, the addition of LHRH agonists to tamoxifen, chemotherapy, or both reduces the risk of recurrence and death after recurrence and LHRH agonists are as effective as chemotherapy. ${ }^{38}$ Thereafter, the National Institutes of Health (NIH) stated, in the consensus development conference statement, that ovarian ablation appears to produce a similar benefit to some chemotherapy regimens and estrogen deprivation can be achieved by the suppression of estrogen synthesis by LHRH agonists in premenopausal women. Ovarian suppression may be considered as an alternative treatment option, instead of chemotherapy, for node-negative endocrine-sensitive early breast cancer. ${ }^{39-41}$ 
Table I Randomized trials evaluating chemotherapy and chemotherapy \pm ovarian suppression

\begin{tabular}{|c|c|c|c|c|c|c|c|c|}
\hline Author & Year & $\begin{array}{l}\text { Type of } \\
\text { study }\end{array}$ & $\begin{array}{l}\text { Patients } \\
\text { (n) }\end{array}$ & Intervention & HR (n) & Primary endpoint & Hazard ratio & $\begin{array}{l}P \text { - } \\
\text { value }\end{array}$ \\
\hline Castiglione- & 2003 & Randomized & 1063 & Goserelin & ER negative & 5-Year DFS (\%) (95\% Cl) & & \\
\hline \multirow[t]{6}{*}{ Gertsch et $\mathrm{a}^{27}$} & & & & CMF & $(3 \mid 5)$ & $73 \%(64-84)$ & $1.13(0.83-1.53)$ & 0.44 \\
\hline & & & & CMF $\rightarrow$ goserelin & & $84 \%(77-91)$ & $0.80(0.57-I .1 I)$ & 0.17 \\
\hline & & & & & & $88 \%(83-9 \mid)$ & 0.7 I $(0.52-0.99)$ & 0.04 \\
\hline & & & & Goserelin & ER positive & $81 \%(76-87)$ & $1.52(0.89-2.58)$ & 0.12 \\
\hline & & & & CMF & $(720)$ & $81 \%(76-87)$ & $0.75(0.40-1.39)$ & 0.35 \\
\hline & & & & $\mathrm{CMF} \rightarrow$ goserelin & & $86 \%(82-91)$ & $0.49(0.28-0.87)$ & 0.01 \\
\hline \multirow[t]{4}{*}{ Davidson et $\mathrm{al}^{28}$} & 2005 & Randomized & 1503 & $\mathrm{CAF}$ & ER positive & 9-Year DFS (\%) & $0.93(0.76-1.12)$ & 0.22 \\
\hline & & & & $\mathrm{CAF} \rightarrow$ goserelin & & $57 \%$ & $0.74(0.60-0.91)$ & $<0.01$ \\
\hline & & & & $\mathrm{CAF} \rightarrow$ goserelin plus & & $60 \%$ & & \\
\hline & & & & tamoxifen & & $68 \%$ & & \\
\hline \multirow[t]{3}{*}{ Arriagada et $\mathrm{a}^{29}$} & 2005 & Randomized & 926 & Chemotherapy ${ }^{a}$ & ER positive & I0-Year OS (\%) (95\% Cl) & $1.2(0.9-1.7)$ & 0.19 \\
\hline & & & & Chemotherapy ${ }^{\mathrm{a}}$ plus ovarian & & $68 \%(63-73)$ & & \\
\hline & & & & suppression $^{\mathrm{b}}$ & & $66 \%(6 I-70)$ & & \\
\hline \multirow{6}{*}{$\begin{array}{l}\text { Kaufmann } \\
\text { et } \mathrm{al}^{30}\end{array}$} & 2007 & Randomized & 776 & Chemotherapy followed by & ER negative & 5-Year EFS (\%) (95\% Cl) & I.0I (0.72-I.42) & 0.97 \\
\hline & & & & goserelin & $(465)$ & $30.8 \%$ & $0.77(0.47-1.24)$ & 0.27 \\
\hline & & & & Standard chemotherapy & ER positive & $30.7 \%$ & & \\
\hline & & & & Chemotherapy followed by & $(3 I I)^{d}$ & $20.6 \%$ & & \\
\hline & & & & goserelin & & $25.8 \%$ & & \\
\hline & & & & Standard chemotherapy & & & & \\
\hline \multirow[t]{3}{*}{ Baum et $\mathrm{al}^{31 \mathrm{e}}$} & 2006 & Meta- & 2710 & Standard adjuvant therapy & ER positive & 5-Year EFS (\%) (95\% Cl) & $0.80(0.69-0.92)$ & 0.002 \\
\hline & & analysis & & Adjuvant therapy plus & & $69.4 \%$ & & \\
\hline & & & & goserelin & & $74.6 \%$ & & \\
\hline Adjuvant Breast & 2007 & Randomized & 2144 & 5 years tamoxifen & ER positive & 5 -Year OS (\%) $(95 \% \mathrm{Cl})$ & & \\
\hline Cancer Trials & & & & $\left( \pm\right.$ chemotherapy $\left.y^{\ddagger}\right)+$ OASg & & $82.6 \%(80-84.9)$ & & \\
\hline Collaborative & & & & 5 years tamoxifen $( \pm$ & & $80.3 \%$ (77.5-82.9) & & \\
\hline Group $^{32}$ & & & & chemotherapyf) & & & & \\
\hline \multirow[t]{3}{*}{ Roché et $\mathrm{a}^{33}$} & 2006 & Randomized & 333 & Triptorelin plus tamoxifen & ER positive & 7-Year DFS (\%) (95\% Cl) & $0.94(0.78-1.13)$ & 0.44 \\
\hline & & & & FEC50 & & $76(68-84)$ & & \\
\hline & & & & & & $72(65-88)$ & & \\
\hline
\end{tabular}

Notes: a CAF/FEC/CMF. 'Ovarian radiation, surgical oophorectomy, or triptorelin. 'N4-9: 4' EC +3' CMF. 'HR-positive patients enrolled after protocol amendment. 'Patients younger than 50 years. ${ }^{\mathrm{f}} \mathrm{CMF} / \mathrm{anthracycline}$ containing/others. ${ }^{8} \mathrm{Ovarian}$ radiation, surgical oophorectomy, or LHRH agonist (triptorelin or leuprorelin acetate).

Abbreviations: $\mathrm{Cl}$, confidence interval; DFS, disease-free survival; HR, hormone receptor; LHRH, luteinizing hormone-releasing hormone; OS, overall survival; CAF, cyclophosphamide, doxorubicin, 5-fluorouracil; FEC, 5- fluorouracil, epirubicin, cyclophosphamide; CMF, cyclophosphamide, methotrexate, 5 fluorouracil; OAS, ovarian ablation or suppression; ER, estrogen-receptor; EFS, event-free survival.

\section{Triptorelin from bench to bedside: the basis for the treatment of breast cancer}

Triptorelin ([D-Ala-6, des-Gly-NH2-10]-LHRH ethylamide) has been synthesized in the late 1970s, and its antitumoral effect in endocrine-sensitive cancers has conducted to its utilization in the treatment of prostate cancer ${ }^{42}$ and breast cancer. ${ }^{43-46}$ Triptorelin was shown to reduce the E2-related activation of c-fos with a subsequent reduction in the transcriptional activity and downregulation of cancer cell proliferation. This effect is observed both in LHRH receptorpositive and -negative cells, whereas it is not observed in the E2-induced pathway. ${ }^{46,47}$

The first clinical evidence for triptorelin efficacy was displayed, as monotherapy, in the treatment of endocrinesensitive metastatic breast cancer. ${ }^{48-55}$ Searching more potent estrogen suppression, the association of triptorelin and formestane, first-generation aromatase inhibitors, was also evaluated, showing the feasibility of the treatment and E2 suppression. ${ }^{56}$

\section{Triptorelin: evolution in the treatment of early breast cancer}

The role of E2 suppression induced by chemotherapy is known: chemotherapy-induced amenorrhea is associated with the reduction of relapse and increased survival outcomes..$^{57,58}$ Patients with HR+ disease and at least 6 months of chemotherapy-related amenorrhea have a reduction in the risk of death or the recurrence of $24 \%(P=0.04)$ and $30 \%(P<0.001)$, respectively. ${ }^{59}$ In order to explore the benefit of amenorrhea, a Phase III French study ${ }^{33}$ compared the hormonal treatment with tamoxifen and LHRH vs epirubicin-based chemotherapy, as adjuvant treatment, in premenopausal women with intermediate-risk HR + breast cancer (1-3 nodes involved and HR+ 
disease). A total of 333 patients were enrolled: 164 patients were randomly assigned to tamoxifen plus LHRH group and 169 patients assigned to chemotherapy group. Amenorrhea occurred in all patients treated with tamoxifen plus LHRH agonist triptorelin (and in 64\% of patients receiving FEC50); after a 7-year follow-up, the study did not showed a difference between the two treatment arms in terms of disease-free survival (DFS) and overall survival (OS). ${ }^{33}$

The prognostic role of treatment-induced amenorrhea (TIA) was evaluated in HER2-positive (HER2+) early breast cancer also. The ALTTO trial, a randomized Phase III study, conducted in patients with HER2+ early breast cancer patients, randomized the women in four adjuvant anti-HER2 arms. The exploratory analysis included 2863 premenopausal women at the time of randomization. This analysis showed that patients with $\mathrm{HR}+$ disease and a TIA had an improvement in both DFS (HR 0.64; 95\% confidence interval [CI] $0.52-0.79$ ) and OS (HR 0.53; 95\% CI 0.38-0.74). On the contrary, in hormone receptor-negative (HR-) disease, DFS and OS were similar between patients independently to TIA status. A cross-talk between HR+ and HER2+ signaling may exist, and its control may improve outcomes in HR+/HER2+ breast cancer. This information supports the use of ovarian suppression therapies in the adjuvant treatment of premenopausal women with HR+/HER2+ early breast cancer. ${ }^{60}$

Two randomized Phase III trials (Tamoxifen and Exemestane Trial [TEXT] and Suppression of Ovarian Function Trial [SOFT]), involving premenopausal women with HR+ early breast cancer treated with hormonal therapy, recently evaluated the role of triptorelin. The TEXT enrolled 2672 patients and was designed to compare 5 years of exemestane plus triptorelin (3.75 mg every 28 days by intramuscular injection) with tamoxifen plus triptorelin (1338 and 1334 patients, respectively, enrolled in the two arms) (Figure 1). ${ }^{61}$ In SOFT, 3066 patients were randomly assigned to the following three different treatment groups: oral tamoxifen only (1021 patients), tamoxifen plus ovarian function suppression (OFS) (1024 patients), and oral exemestane plus OFS for 5 years (1021 patients) (Figure 2). OFS was achieved by bilateral oophorectomy, bilateral ovarian irradiation, or using triptorelin $3.75 \mathrm{mg}$ every 28 days. ${ }^{61}$ In TEXT, the patients treated with chemotherapy received concurrent OFS (triptorelin) after randomization that was always used in the first 6 months after randomization. Afterward, patients could continue treatment with the LHRH analog or change to oophorectomy or ovarian radiation therapy, while in SOFT, patients who received chemotherapy (neoadjuvant or adjuvant), and who remained premenopausal, underwent randomization within 8 months from the end of chemotherapy. ${ }^{61}$ For both, the primary endpoint was DFS. In SOFT, the addition of OFS to tamoxifen did not significantly improve DFS in the overall population: the 5-year DFS rate was $86.6 \%$ in the tamoxifen plus OFS group and $84.7 \%$ in the tamoxifen alone group (HR 0.83; 95\% CI 0.66-1.04; $P=0.10)$. Multivariate analysis reported a $22 \%$ reduction in the risk of disease progression in the tamoxifen plus OFS group (HR 0.78; 95\% CI 0.62-0.98). Of note, the addition of OFS improved disease outcomes in women treated with adjuvant chemotherapy and in the younger ones (Table 2). ${ }^{62}$ In the joint analysis of the two trials, which included 4690 premenopausal women with HR+ breast cancer, adjuvant endocrine therapy with exemestane plus OFS significantly improved DFS over tamoxifen plus

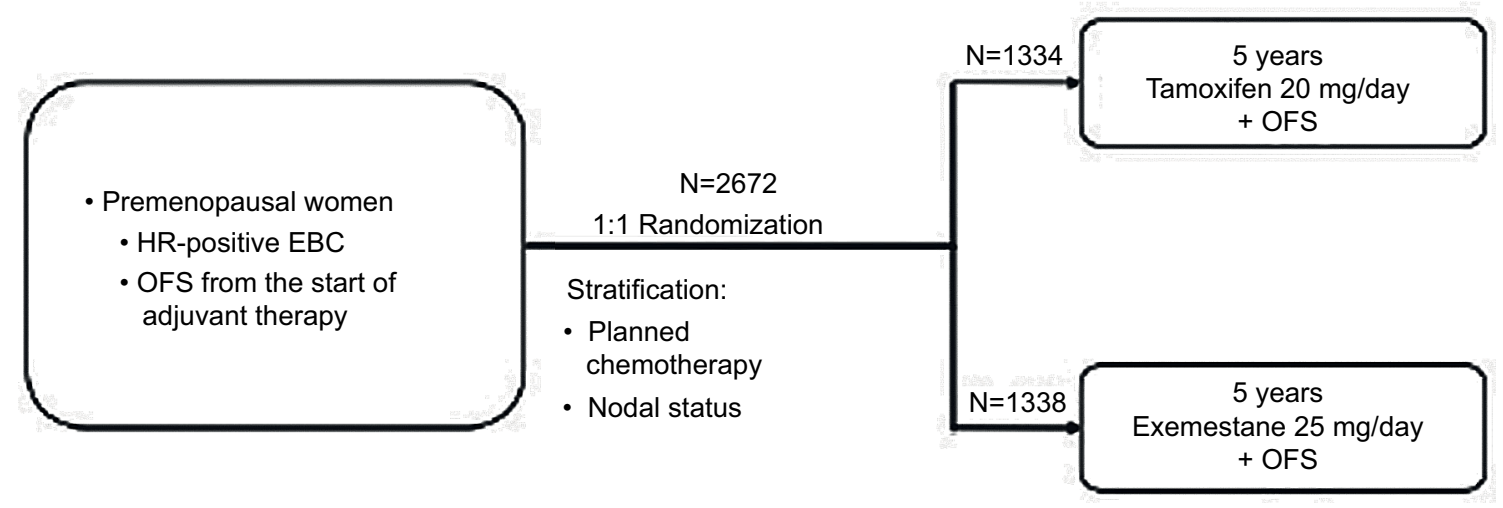

Figure I TEXT study description.

Notes: OFS achieved using triptorelin $3.75 \mathrm{mg}$ every 28 days. Bilateral oophorectomy or ovarian irradiation was allowed at least 6 months of triptorelin after randomization. Optional chemotherapy: if administered was started concomitantly with triptorelin followed by oral endocrine therapy after the completion of chemotherapy. If chemotherapy was not administered, oral endocrine therapy was started 6-8 weeks after the initiation of triptorelin.

Abbreviations: EBC, early breast cancer; HR, hormone receptor; OFS, ovarian function suppression; TEXT, Tamoxifen and Exemestane Trial. 


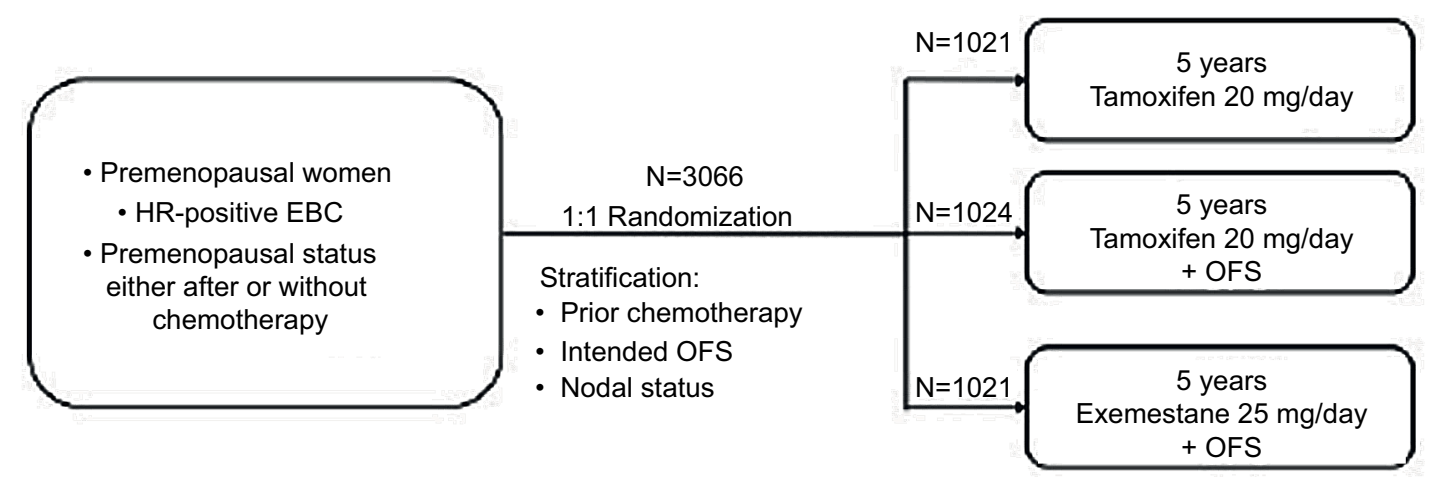

Figure 2 SOFT trial study description.

Notes: OFS achieved using triptorelin $3.75 \mathrm{mg}$ every 28 days, bilateral oophorectomy or ovarian irradiation. Patients randomized to receive endocrine therapy \pm OFS between 12 weeks of surgery or within 8 months of neoadjuvant chemotherapy.

Abbreviations: EBC, early breast cancer; HR, hormone receptor; OFS, ovarian function suppression; SOFT, Suppression of Ovarian Function Trial.

OFS, showing a reduction of $34 \%$ in the risk of breast cancer recurrence with exemestane over tamoxifen (HR 0.66; 95\% CI $0.55-0.80 ; P<0.001)$. No significant difference in OS was reported, and this could be due to the brevity of the follow-up to identify such difference. ${ }^{63}$ The toxicity profile was similar between the two groups, and the DFS benefit was achieved without a detrimental effect of exemestane plus OFS on the quality of life, when compared with tamoxifen plus OFS ${ }^{64} \mathrm{~A}$ recent planned update at 8 years for the SOFT and at 9 years for the combined TEXT and SOFT showed that the addition of LHRH to tamoxifen or exemestane significantly improved the outcome compared to tamoxifen alone. It also confirms the efficacy of exemestane plus OFS over tamoxifen with a $4 \%$ absolute improvement in DFS at 8 years. ${ }^{65,66}$ A successive further analysis that included 4891 women who were enrolled in the two trials and evaluated breast cancer-free interval (BCFI) according to clinicopathologic features was performed. The results showed that the greater benefit derived from exemestane plus OFS is given to high recurrence-risk patients who may experience an improvement of 10-15\% in 5-year BCFI. Therefore, not all premenopausal women should receive the combination, but a balance between risks, expected benefits, and toxicities is needed. ${ }^{67}$ The basis for the efficacy of the association of aromatase inhibitors and LHRH analogs was explored in an Italian Phase III trial that compared the endocrine effects of 6 months of adjuvant treatment with tamoxifen and triptorelin or letrozole and triptorelin in 81 premenopausal women with early breast cancer. ${ }^{68}$ The letrozole group has shown a major suppression of median E2 serum levels $(P=0.0008)$ compared with tamoxifen; otherwise, FSH median levels were lower in patients receiving tamoxifen $(P<0.0001)$. These results have led to the hypothesis that the greater efficacy of letrozole found in postmenopause ${ }^{69}$ could be confirmed also in premenopausal women. Of note, this greater suppression is related to a greater incidence of adverse effects (ie, osteoporosis, alteration of lipid metabolism, and sexual function impairment) that must be taken into consideration in younger women. ${ }^{68}$

The possibility of incomplete estrogen suppression has been described in the SOFT-EST substudy. E2, estrone (E1), and E1 sulfate (E1S) levels were measured during the first year of monthly triptorelin plus exemestane or tamoxifen using a more specific and sensitive method (gas chromatography tandem mass spectrometry), among patients receiving exemestane plus triptorelin. Two-thirds of premenopausal patients treated with exemestane plus triptorelin showed a profound, persistent reduction in E2 levels during the first 12 months of treatment. This decrease was significantly lower than in the tamoxifen plus triptorelin group at all time points, although $17 \%$ of patients had an E2 level greater than the lower estimated level of $2.72 \mathrm{pg} / \mathrm{mL}$ at each time point. Interestingly, 34\% (27/79) of patients, receiving exemestane plus triptorelin, had an E2 level greater than the predefined threshold and had at least one postbaseline E2 value $>2.72 \mathrm{pg} / \mathrm{mL}$. Baseline factors related to E2 level $>2.72 \mathrm{pg} / \mathrm{mL}$ were as follows: no prior chemotherapy $(P=0.06)$, higher body mass index $(P=0.05)$, and lower FSH and $\mathrm{LH}$ (each $P<0.01){ }^{70}$

Some reflections on the efficacy of LHRH analogs in the adjuvant setting could also be extrapolated from two trials conducted to explore the likelihood to preserve the ovarian function. The PROMISE-GIM6 trial was designed to evaluate the incidence of early menopause in young women with breast cancer treated with (neo)adjuvant chemotherapy plus temporary ovarian suppression obtained by the administration of triptorelin. ${ }^{71}$ A post hoc extension of the study was conducted 
Table 2 Ovarian function suppression and outcome results

\begin{tabular}{|c|c|c|c|c|c|c|}
\hline Author & Year & Patients (n) & Treatment arms & DFS (\%) & HR (95\% Cl) & $P$-value \\
\hline Pagani et al ${ }^{66}$ & 2017 & 4690 & Exemestane + OFS & 86.8 & $0.77(0.67-0.90)$ & 0.0006 \\
\hline \multirow[t]{3}{*}{ Francis et $\mathrm{al}^{62}$} & 2015 & 3066 & Tamoxifen + OFS & 82.8 & $0.83(0.66-1.04)$ & 0.10 \\
\hline & & & Tamoxifen + OFS & 86.6 & & \\
\hline & & & Tamoxifen & 84.7 & & \\
\hline \multirow[t]{2}{*}{ Lambertini et a $\mathrm{l}^{72}$} & 2015 & 281 & $\mathrm{CT}+$ triptorelin & 80.5 & $1.17(0.72-1.92)$ & 0.52 \\
\hline & & & $\mathrm{CT}$ alone & 83.7 & & \\
\hline \multirow[t]{2}{*}{ Moore et al ${ }^{89}$} & 2017 & 218 & $C T+$ goserelin & 88.0 & $0.50(0.24-0.97)$ & 0.05 \\
\hline & & & $\mathrm{CT}$ alone & 79.0 & & \\
\hline
\end{tabular}

Note: ${ }^{2}$-Year DFS.

Abbreviations: $\mathrm{Cl}$, confidence interval; CT, chemotherapy; DFS, disease-free survival; HR, hazard ratio; OFS, ovarian function suppression.

to evaluate long-term outcomes including long-term ovarian function, pregnancy, and DFS. Two hundred eighty patients were enrolled; >5-year DFS was 80.5\% (95\% CI 76.1-89.1\%) in the LHRH analog group and $83.7 \%$ in the control group with an HR of 1.17 (95\% CI $0.72-1.92 ; P=0.52)$, so the difference was not statistically significant. This increased risk appeared to be more prevalent in women with HR- cancer with a 5-year DFS of $62.1 \%$ in the experimental arm and $76.2 \%$ in the control arm, with an HR of 2.11 (95\% CI 0.74-5.98) (Table 2). By contrast, in the HR+ patients, the difference between the two arms was not statistically significant, with an HR of 0.96 (95\% CI 0.55-1.70); possibly, the lack of statistical significance could be related to the study being underpowered. ${ }^{72}$ These findings are discordant with the results of the POEMS-SWOG SO230 study, which showed an advantage in 4-year DFS in 105 women treated with chemotherapy plus goserelin as compared with 113 women treated with chemotherapy alone ( 89 vs $78 \%$, respectively, with an HR of $0.49 ; 95 \%$ CI $0.24-0.97 ; P=0.04$ ) (Table 2 ). ${ }^{73}$ A similar improvement was found in terms of OS with an HR of 0.43 ( $P=0.05)$. Of note, the trial enrolled only patients with ER-negative disease, confirming the safety of the concurrent administration of chemotherapy and LHRH agonist in this subset of patients. ${ }^{73}$ The improvement in these outcomes was unexpected in this population, but it is concordant with preclinical evidence in the setting of triple-negative breast cancer suggesting the presence of high expression of LHRH receptors in this breast cancer subtype. Therefore, the use of LHRH analogs may be even related to cancer cells' growth inhibition and reduction in metastatic spread. ${ }^{74,75}$

\section{Triptorelin and preservation of ovarian function}

Great interest rises up from the opportunity of LHRH analogs use in premenopausal women during chemotherapy treatment in order to preserve ovarian function. In the last few years, due to the improvement in the prognosis of cancer patients, growing attention has been given to the long-term consequences of the treatment, in particular to the fertility issue especially if we consider that $41 \%$ of breast cancers are diagnosed in patients younger than 50 years. ${ }^{76}$ In young cancer patients, ovarian toxicity is a primary side effect of chemotherapy for those who often need and receive aggressive multimodality treatment; cancer survivors have reduced pregnancy rates when compared with the general population. ${ }^{77}$ According to a big nationwide Norwegian study, published in 2011, female survivors have the lowest chance of subsequent pregnancy after a breast cancer diagnosis. This is $\sim 70 \%$ lower than the general population. ${ }^{77}$ These data are even more important considering the percentage of women who wish to become pregnant. According to a study published by Letourneau et $\mathrm{al}^{78}$ on cancer in $2012,47 \%$ of young patients with breast cancer would like to get pregnant after treatment. The concerns about the possible loss of ovarian function and fertility can affect the treatment decisions of a significant percentage of young patients at the time of breast cancer diagnosis. In 2014, Ruddy et $\mathrm{al}^{79}$ published the results of a survey as part of a prospective multicenter cohort study: 319 (51\%) of the 620 women were concerned about becoming infertile after treatment. Due to fertility concerns, four (1\%) women chose not to receive chemotherapy, 12 (2\%) women chose one chemotherapy regimen over another, six (1\%) women considered not receiving endocrine therapy, 19 (3\%) women decided not to receive endocrine therapy, and 71 (11\%) women considered receiving endocrine therapy for 5 years; $65(10 \%)$ women used fertility preservation strategies. The population more concerned about fertility was women of a younger age, non-White race, childless, and who had to start chemotherapy. ${ }^{79}$ These results are in accordance with the previous study published by Partridge et $\mathrm{al}^{80}$ in 2004: $73 \%$ of women with BC were concerned about fertility, $57 \%$ of women were seriously concerned about sterility, and $29 \%$ of 
women did not comply with their treatment because of fertility issues. Premature ovarian failure (POF) is one possible effect of chemotherapy in premenopausal patients and even in the presence of resumed regular menses after treatment patients are still at risk of developing early menopause due to the damage of cytotoxic therapy to their ovarian reserve. The effects of chemotherapy on ovarian function are variable and related to the age of the woman, pre-existing ovarian reserve, and type and dose of chemotherapy. ${ }^{81}$ Risk is particularly significant in those patients who are eligible to receive neoadjuvant or adjuvant chemotherapy with alkylating agents; HR + disease implies adjuvant endocrine therapy for 5-10 years with a further delay in pregnancy and women older than 40 years. $^{82}$

Nowadays, major international guidelines recommend early discussion about fertility issues with young patients to help them make an informed decision and this process is an important component of quality oncology care. ${ }^{83-87}$ The clinicians should discuss the risks for infertility, fertility preservation, and the probability of successful pregnancies subsequent to the completion of BC therapy. In Italy, according to a survey published in 2015 by Biglia et al, ${ }^{88} 91 \%$ of oncologists considered it important to discuss the issue of fertility and $93 \%$ of them introduced this topic when the patient did not talk about it. At this current moment, the available options for premenopausal breast cancer patients are embryo or oocyte cryopreservation, ovarian tissue cryopreservation, and temporary menstrual suppression with LHRH analogs during chemotherapy; more than one technique can be used at the same time.

In order to evaluate the safest strategy to preserve fertility, two major trials have been conducted in breast cancer patients in the last years. The Prevention of Early Menopause Study (POEMS-SWOG $)^{73}$ showed that temporary ovarian suppression with goserelin during chemotherapy was associated with a significant reduction in the risk of treatment-related POF (8 vs 22\%; OR 0.30; 95\% CI 0.09-0.97) (Table 3). The updated results presented at San Antonio Breast Cancer Symposium (SABCS) 2017 after a median follow-up of 5.1 years showed higher pregnancy rates in the goserelin group compared with those in the standard group (22 vs $12 \%$; OR 2.38 ; $95 \%$ CI $1.08-5.26, P=0.05)$; this has been associated with improved survival with a significant increase in both DFS and OS in the LHRH analog containing group. ${ }^{89}$ The second one is the Italian Study (PROMISE-GIM6) conducted by Del Mastro et $\mathrm{al}^{71}$ which showed a significant protective effect with the use of LHRH analog triptorelin in preserving ovarian function 1 year after the end of chemotherapy ( 9 vs $26 \%$; OR 0.28 ; 95\% CI 0.14-0.59) and also at long-term follow-up (Table 3 ). Furthermore, an increased pregnancy rate was reported by both the studies. ${ }^{71,73}$ This information was confirmed in a meta-analysis published in 2015 that included 12 randomized studies: the use of GHRH analogs was associated with a significant reduced risk of POF (OR 0.36; $P<0.001)$ and a significantly increased number of pregnancies (33 vs 19 women; OR 1.83; $P=0.041$ ) with no apparent negative impact on patients' prognosis (Table 3 ). ${ }^{90}$ This finding seems to conclude the long debate behind the pharmacological protection for fertility preservation and in the light of this evidence; the last version of Italian guidelines regarding the issue of fertility recommends this strategy in all premenopausal patients undergoing chemotherapy. ${ }^{87}$

There is no complete agreement on the role of LHRH analogs on the preservation of fertility, according to the sec-

Table 3 Triptorelin and ovarian function preservation

\begin{tabular}{|c|c|c|c|c|c|c|c|c|}
\hline Author & Year & $\begin{array}{l}\text { Patients } \\
\text { randomized } \\
\text { (control/ } \\
\text { experimental) }\end{array}$ & $\begin{array}{l}\text { Median age, } \\
\text { years (control/ } \\
\text { experimental) }\end{array}$ & $\begin{array}{l}\text { HR status } \\
\text { (positive/ } \\
\text { negative) }\end{array}$ & $\begin{array}{l}\text { Endocrine } \\
\text { therapy }+ \\
\text { triptorelin }\end{array}$ & Definition of POF & $\begin{array}{l}\text { Timing } \\
\text { of POF } \\
\text { evaluation } \\
\text { (months) }\end{array}$ & $\begin{array}{l}\text { OR for POF defined } \\
\text { as amenorrhea } \\
\text { I year after the end } \\
\text { of chemotherapy } \\
(95 \% \mathrm{Cl})\end{array}$ \\
\hline $\begin{array}{l}\text { Del Mastro } \\
\text { et } \mathrm{al}^{71}\end{array}$ & 2011 & $133 / 148$ & $39 / 39$ & $26 / 51$ & Tamoxifen & $\begin{array}{l}\text { No resumption } \\
\text { of menses and }\end{array}$ & 12 & $0.56(0.35-0.90)$ \\
\hline $\begin{array}{l}\text { Lambertini } \\
\text { et a }{ }^{97}\end{array}$ & 2014 & & & & & $\begin{array}{l}\text { postmenopausal } \\
\text { levels of FSH and E2 }\end{array}$ & & \\
\hline $\begin{array}{l}\text { Munster } \\
\text { et } \mathrm{a}^{94}\end{array}$ & 2012 & $38 / 39$ & $32 / 33$ & $16 / 20$ & Tamoxifen & $\begin{array}{l}\text { No resumption of } \\
\text { menses }\end{array}$ & 12 & $0.74(0.2 \mathrm{I}-2.58)$ \\
\hline $\begin{array}{l}\text { Elgindy } \\
\text { et a| }{ }^{98, a}\end{array}$ & 2013 & $50 / 50$ & $40 / 42$ & $0 / 100$ & - & $\begin{array}{l}\text { No resumption of } \\
\text { menses }\end{array}$ & 12 & $\begin{array}{l}0.76(0.18-3.25) \\
1.00(0.25-4.00)\end{array}$ \\
\hline
\end{tabular}

Notes: a This study was analyzed considering the following comparisons: early chemotherapy-alone vs early chemotherapy + LHRHa + LHRH antagonist (ie, "Elgindy I") and delayed chemotherapy vs delayed chemotherapy + LHRHa.

Abbreviations: $\mathrm{Cl}$, confidence interval; E2, estradiol; FSH, follicle-stimulating hormone; HR, hormone receptor; LHRH, luteinizing hormone-releasing hormone; LHRHa, LHRH analog; POF, premature ovarian failure. 
ond international consensus guidelines for breast cancer in young women (BCY2). ${ }^{85}$ While in the St Gallen International Expert Consensus on the Primary Therapy of Early Breast Cancer $^{91}$ and in National Comprehensive Cancer Network (NCCN) guidelines, ${ }^{83}$ this strategy should be discussed with the patients; in the American Society of Clinical Oncology $(\mathrm{ASCO})^{86}$ and European Society for Medical Oncology $(\mathrm{ESMO})^{84}$ guidelines, the use of LHRH during chemotherapy is not recommended because it is considered as an experimental technique. The major reason for this difference is probably that the latest version of ASCO and ESMO guidelines were published in 2013 and an update is needed to encompass this new information. ${ }^{84,86}$ The recent result of the Phase III study $\left(\mathrm{OPTION}^{92}\right)$ has shown that the use of LHRH analog (goserelin) provides some protection to the ovarian function during chemotherapy in women younger than 40 years. The effect seems to be uncertain for women who are older than 40 years ( $\leq 40$ amenorrhea: 10 vs $25.4 \%, P=0.032$, premature ovarian insufficiency (POI): 2.6 vs 20\%, $P=0.038$; $>40$ amenorrhea: 42.9 vs $54.2 \%, P=0.376$, POI: 42.3 vs $47.2 \%, P=0.798) .{ }^{92}$ These results are in the same direction of two other studies and a meta-analysis. The results of the meta-analysis from five randomized clinical trials (PROMISE-GIM6, ${ }^{71}$ POEMS/ SWOG,${ }^{73}$ OPTION,${ }^{92}$ GBG 37 ZORO, ${ }^{93}$ and Moffitt Cancer Center-led trial $\left.{ }^{94}\right)$, in which premenopausal women with early breast cancer (EBC) were randomized to receive chemotherapy alone or with LHRH (437 or 436 women, respectively), have been recently presented by the Lambertini et al at the SABCC 2017. The POI rate was $14.1 \%$ in the LHRH group and $30.9 \%$ in the control group (adjusted OR 0.38; $95 \% \mathrm{CI}$ $0.26-0.57 ; P<0.001)$, and the post-treatment pregnancy rate was 37 in the LHRH group vs 20 in the control group (incidence rate ratio $1.83 ; 95 \%$ CI $1.06-3.15 ; P=0.030)$. Similar DFS and OS were observed between groups regardless of the ER status. ${ }^{95}$ According to some of the principal authors in this field, the puzzle on the protective role of temporary ovarian suppression with LHRH analogs during chemotherapy has been completed. ${ }^{96}$

\section{Conclusion}

After several years of debate and studies, the role of LHRH analogs appears more definite to the adjuvant treatment of premenopausal women with endocrine-sensitive breast cancer. First, the adjuvant trials (TEXT/SOFT) point out the adequate length of LHRH treatment in the premenopausal setting and delineate the class of risk in which LHRH appears more beneficial; 5 years of LHRH treatment is an adequate treatment length in the high-risk setting, whereas it is not beneficial in the low-risk subset. The role of LHRH was also explored in the preservation of the ovarian function allowing the oncologist the possibility of offering a safe and effective treatment together with the other existing fertility preservation techniques. Triptorelin represents one of the LHRH analogs available in clinical practice worldwide; it has been extensively studied in various trials that have confirmed the magnitude of its effectiveness in the adjuvant treatment of early breast cancer in the premenopausal setting and represents a safe and successful treatment.

\section{Acknowledgments}

This review has been conducted following the Cochrane Handbook for Systematic Reviews of Interventions Version 5.1.0 (updated March 2011). The objective of this review was to specifically evaluate the role of LHRH analog triptorelin in the management of early breast cancer. The types of studies selected in this review were as follows: randomized controlled clinical trials and their related updates, meta-analyses, and relevant published studies concerning the role of triptorelin in the breast cancer treatment. Also, the published trials and their related updates, concerning the role of triptorelin, and other LHRH analogs were selected to evaluate its role in the preservation of ovarian function in the early breast cancer setting.

\section{Author contributions}

All authors contributed toward data analysis, drafting and critically revising the paper and agree to be accountable for all aspects of the work.

\section{Disclosure}

The authors report no conflicts of interest in this work.

\section{References}

1. Shupnik MA. Gonadotropin gene modulation by steroids and gonadotropin-releasing hormone. Biol Reprod. 1996;54(2):279-286.

2. Conn PM, Crowley WF Jr. Gonadotropin-releasing hormone and its analogs. Аппи Rev Med. 1994;45:391-405.

3. Kakar SS, Grizzle WE, Neill JD. The nucleotide sequences of human GnRH receptors in breast and ovarian tumors are identical with that found in pituitary. Mol Cell Endocrinol. 1994;106(1-2):145-149.

4. Kottler ML, Starzec A, Carre MC, Lagarde JP, Martin A, Counis R. The genes for gonadotropin-releasing hormone and its receptor are expressed in human breast with fibrocystic disease and cancer. Int $J$ Cancer. 1997;71(4):595-599.

5. Miller WR, Scott WN, Morris R, Fraser HM, Sharpe RM. Growth of human breast cancer cells inhibited by a luteinizing hormone-releasing hormone agonist. Nature. 1985;313(5999):231-233. 
6. Kéri G, Balogh A, Szöke B, Teplán I, Csuka O. Gonadotropin-releasing hormone analogues inhibit cell proliferation and activate signal transduction pathways in MDA-MB-231 human breast cancer cell line. Tumour Biol. 1991;12(2):61-67.

7. Blankestein MA, Henkelman MS, Klijn JGM. Direct inhibitor effect of a luteinising hormone-releasing hormone agonist on MCF-7 human breast cancer cells. Eur J Cancer Clin Oncol. 1985;21(12):1493-1499.

8. Fekete M, Wittliff JL, Schally AV. Characteristics and distribution of receptors for D-Trp ${ }^{6}$-luteinizing hormone, somatostatin. epidermal growth factor, and sex steroids in 500 biopsy samples of human breast cancer. J Clin Lab Anal. 1989;3(3):137-147.

9. Srkalovic G, Szende B, Redding TW, Groot K, Schally AV. Receptors for D-Trp6-luteinizing hormone-releasing hormone, somatostatin, and insulin-like growth factor I in MXT mouse mammary carcinoma. Proc Sac Exp Biol Med. 1989;192(3):209-218.

10. Milovanovic SR, Radulovic S, Schally AV. Evaluation of binding of cytotoxic analogs of luteinizing hormone-releasing hormone to human breast cancer and mouse MXT mammary tumor. Breast Cancer Res Treat. 1992;24(2):147-158.

11. Stojilkovic SS, Catt KJ. Expression and signal transduction pathways of gonadotropin-releasing hormone receptors. Recent Prog Horm Res. 1995;50:161-205.

12. Naor Z, Harris D, Shacham S. Mechanism of GnRH receptor signalling: combinatorial cross-talk of $\mathrm{Ca} 2+$ and protein kinase C. Front Neuroendocrinol. 1998;19(1):1-19.

13. Gründker C, Völker P, Emons G. Antiproliferative signaling of luteinizing hormone-releasing hormone in human endometrial and ovarian cancer cells through G-protein alpha(I)-mediated activation of phosphotyrosine phosphatase. Endocrinology. 2001;142(6):2369-2380.

14. Drean YL, Liu D, Wong AO, Xiong F, Hew CL. Steroidogenic factor 1 and estradiol receptor act in synergism to regulate the expression of the salmon gonadotropin II beta subunit gene. Mol Endocrinol. 1996;10(3): 217-229.

15. Xie W, Duan R, Safe S. Estrogen induces adenosine deaminase gene expression in MCF-7 human breast cancer cells: role of estrogen receptor-Sp1 interactions. Endocrinology. 1999;140(1):219-227.

16. Li C, Briggs MR, Ahlborn TE, Kraemer FB, Liu J. Requirement of Sp1 and estrogen receptor alpha interaction in 17beta-estradiol-mediated transcriptional activation of the low density lipoprotein receptor gene expression. Endocrinology. 2001;142(4):1546-1553.

17. Wang W, Dong L, Saville B, Safe S. Transcriptional activation of E2F1 gene expression by 17 beta-estradiol in MCF-7 cells is regulated by NF-Y-Sp1/estrogen receptor interactions. Mol Endocrinol. 1999;13(8): 1373-1387.

18. Paech K, Webb P, Kuiper GG, et al. Differential ligand activation of estrogen receptors ERalpha and ERbeta at AP1 sites. Science. 1997;277(5331):1508-1510.

19. Jakacka M, Ito M, Weiss J, Chien PY, Gehm BD, Jameson JL. Estrogen receptor binding to DNA is not required for its activity through the nonclassical AP1 pathway. J Biol Chem. 2001;276(17):13615-13621.

20. Watters JJ, Campbell JS, Cunningham MJ, Krebs EG, Dorsa DM. Raid membrane effects of steroids in neuroblastoma cells: effects of estrogen on mitogen activated protein kinase signaling cascade and c-fos immediate early gene transcription. Endocrinology. 1997;138(9):4030-4033.

21. Beatson GT, Edin MD. On the treatment of inoperable cases of carcinoma of the mamma: suggestions for a new method of treatment, with illustrative cases. Lancet. 1896;148(3803):162-165.

22. Paterson R, Russell MH. Clinical trials in malignant disease: part II breast cancer: value of irradiation of the ovaries. J Fac Radiol. 1959;10(3):130-133.

23. Walker KJ, Walker RF, Turkes A, et al. Endocrine effects of combination antioestrogen and LH-RH agonist therapy in premenopausal patients with advanced breast cancer. Eur J Cancer Clin Oncol. 1989;25(4):651-654.

24. Nicholson RI, Walker KJ, McClelland RA, Dixon A, Robertson JF, Blamey RW. Zoladex plus tamoxifen versus Zoladex alone in pre- and peri-menopausal metastatic breast cancer. J Steroid Biochem Mol Biol. 1990;37(6):989-995.
25. Robertson JF, Walker KJ, Nicholson RI, Blamey RW. Combined endocrine effects of LHRH agonist (Zoladex) and tamoxifen (Nolvadex) therapy in premenopausal women with breast cancer. Br J Surg. 1989;76(12):1262-1265.

26. Cohen I, Tepper R, Figer A, Flex D, Shapira J, Beyth Y. Successful cotreatment with LHRH-agonist for ovarian over-stimulation and cystic formation in premenopausal tamoxifen exposure. Breast Cancer Res Treat. 1999;55(2):119-125.

27. International Breast Cancer Study Group (IBCSG), Castiglione-Gertsch M, O'Neill A, et al. Adjuvant chemotherapy followed by goserelin versus either modality alone for premenopausal lymph node-negative breast cancer: a randomized trial. J Natl Cancer Inst. 2003;95(24):1833-1846.

28. Davidson NE, O'Neill AM, Vukov AM, et al. Chemoendocrine therapy for premenopausal women with axillary lymph node-positive, steroid hormone receptor-positive breast cancer: results from INT 0101 (E5188). J Clin Oncol. 2005;23(25):5973-5982.

29. Arriagada R, Lê MG, Spielmann M, et al. Randomized trial of adjuvant ovarian suppression in 926 premenopausal patients with early breast cancer treated with adjuvant chemotherapy. Ann Oncol. 2005;16(3):389-396.

30. Kaufmann M, Graf E, Jonat W, et al. A randomised trial of goserelin versus control after adjuvant, risk-adapted chemotherapy in premenopausal patients with primary breast cancer - GABG-IV B-93. Eur $J$ Cancer. 2007;43(16):2351-2358.

31. Baum M, Hackshaw A, Houghton J, et al. Adjuvant goserelin in premenopausal patients with early breast cancer: results from the ZIPP study. Eur J Cancer. 2006;42(7):895-904.

32. Adjuvant Breast Cancer Trials Collaborative Group. Ovarian ablation or suppression in premenopausal early breast cancer: results from the international adjuvant breast cancer ovarian ablation or suppression randomized trial. J Natl Cancer Inst. 2007;99(7):516-525.

33. Roché H, Kerbrat P, Bonneterre J, et al. Complete hormonal blockade versus epirubicin-based chemotherapy in premenopausal, one to three node-positive, and hormone-receptor positive, early breast cancer patients: 7-year follow-up results of French Adjuvant Study Group 06 randomised trial. Ann Oncol. 2006;17(8):1221-1227.

34. Early Breast Cancer Trialists' Collaborative Group. Systemic treatment of early breast cancer by hormonal, cytotoxic, or immune therapy: 133 randomised trials involving 31,000 recurrences and 24,000 deaths among 75,000 women. Lancet. 1992;339(8785):71-85.

35. Early Breast Cancer Trialists' Collaborative Group. Ovarian ablation in early breast cancer: overview of the randomised trials. Lancet. 1996;348(9036):1189-1196.

36. Sharma R, Hamilton A, Beith J. LHRH agonists for adjuvant therapy of early breast cancer in premenopausal women. Cochrane Database Syst Rev. 2008;(4):CD004562.

37. Early Breast Cancer Trialists' Collaborative Group. Effects of chemotherapy and hormonal therapy for early breast cancer on recurrence and 15-year survival: an overview of the randomised trials. Lancet. 2005;365(9472):1687-1717.

38. LHRH-Agonists in Early Breast Cancer Overview Group, Cuzick J, Ambroisine $\mathrm{L}$, et al. Use of luteinising-hormone-releasing hormone agonists as adjuvant treatment in premenopausal patients with hormonereceptor-positive breast cancer: a meta-analysis of individual patient data from randomised adjuvant trials. Lancet. 2007;369(9574):1711-1723.

39. Eifel P, Axelson JA, Costa J, et al. National Institutes of Health Consensus Development conference statement: adjuvant therapy for breast cancer, November 1-3, 2000. J Natl Cancer Inst. 2001;93(13):979-989.

40. Goldhirsch A, Glick JH, Gelber RD, Coates AS, Senn HJ. Meeting highlights: International Consensus Panel on the treatment of primary breast cancer. Seventh International Conference on adjuvant therapy of primary breast cancer. J Clin Oncol. 2001;19(18):3817-3827.

41. Blamey RW, for EUSOMA. Guidelines on endocrine therapy of breast cancer EUSOMA. Eur J Cancer. 2002;38(5):615-634.

42. Tolis G, Ackman D, Stellos A, et al. Tumor growth inhibition in patients with prostatic carcinoma treated with luteinizing hormone-releasing hormone agonists. Proc Natl Acad Sci U S A. 1982;79(5):1658-1662. 
43. Redding TW, Schally AV. Inhibition of mammary tumor growth in rats and mice by administration of agonistic and antagonistic analogs of luteinizing hormone-releasing hormone. Proc Natl Acad Sci U S A. 1983;80(5):1459-1462.

44. Schally AV, Redding TW, Comaru-Schally AM. Inhibition of the growth of some hormone dependent tumors by D-Trp6-LH-RH. Med Oncol Tumor Pharmacother. 1984;1(2):109-118.

45. Néri C, Blangy D, Schatz B, Drieu K, Berebbi M, Martin PM. Direct inhibiting effects of [D-Trp6]gonadotropin-releasing hormone on the estrogen-sensitive progression of polyoma virus-induced mammary tumors in athymic mice. Cancer Res. 1990;50(18):5892-5897.

46. Gründker C, Günthert AR, Hellriegel M, Emons G. Gonadotropinreleasing hormone $(\mathrm{GnRH})$ agonist triptorelin inhibits estradiol-induced serum response element (SRE) activation and c-fos expression in human endometrial, ovarian and breast cancer cells. Eur J Endocrinol. 2004;151(5):619-628.

47. Pasqualini JR, Blumberg-Tick J, Nguyen BL. Effect of triptorelin (Decapeptyl) combined with heparin on estradiol levels in MCF-7 mammary cancer cells after incubation with estrone sulfate. Acta Endocrinol (Copenh). 1993;129(3):260-262.

48. Klijn JGM, De Jong FH. Treatment with a luteinising hormone releasing hormone analogue (buserelin) in pre-menopausal patients with metastatic breast cancer. Lancet. 1982;319(8283):1213-1216.

49. Klijn JG, De Jong FH, Lamberts SW, Blankenstein MA. LHRH agonist treatment in clinical and experimental human breast cancer. $J$ Steroid Biochem. 1985;23(5B):867-873.

50. Plowman PN, Nicholson RI, Walker KJ. Remission of postmenopausal breast cancer during treatment with the luteinising hormone releasing hormone agonist ICT 118630. Br J Cancer. 1986;54:903-909.

51. Schwartz L, Guiochet N, Keiling R. Two partial remissions induced by a LHRH analogue in two postmenopausal women with metastatic breast cancer. Cancer. 1988;62(12):2498-2500.

52. Nesković-Konstantinović ZB, Vuletić LB, Nikolić-Stanojević LI, et al. Therapeutic and endocrine effects of Decapeptyl, synthetic LH-RH agonistic analogue in premenopausal women with metastatic breast cancer. A pilot phase II study. Oncology. 1994;51(1):95-101.

53. Marini L, Iacopino F, Schinzari G, Robustelli della Cuna FS, Mantovani G, Sica G. Direct antiproliferative effect of triptorelin on human breast cancer cells. Anticancer Res. 1994;14(5A):1881-1885.

54. Sanchez-Garrido F, Comaru-Schally AM, Sanchez del Cura G, Gonzales-Enriquez J, Schally AV. Clearance of lung metastases of breast carcinoma after treatment with triptorelin in postmenopausal woman. Lancet. 1995;345(8953):868.

55. Garcia-Giralt E, Beuzeboc P, Dieras V, et al. Phase II trial of decapeptyl (D-TRP-6), a potent luteinizing hormone-releasing hormone analogue in untreated advanced breast cancer. Am J Clin Oncol. 1996;19(5): 455-458.

56. Celio L, Martinetti A, Ferrari L, et al. Premenopausal breast cancer patients treated with a gonadotropin-releasing hormone analog alone or in combination with an aromatase inhibitor: a comparative endocrine study. Anticancer Res. 1999;19(3B):2261-2268.

57. Goldhirsch A, Gelber RD, Castiglione M. The magnitude of endocrine effects of adjuvant chemotherapy for premenopausal breast cancer patients: the International Breast Cancer Study Group. Ann Oncol. 1990;1(3):183-188.

58. Bianco AR, Del Mastro L, Gallo C, et al. Prognostic role of amenorrhoea induced by adjuvant chemotherapy in premenopausal patients with early breast cancer. Br J Cancer. 1991;63(5):799-803.

59. Swain SM, Jeong JH, Geyer CE Jr, et al. Longer therapy, iatrogenic amenorrhea, and survival in early breast cancer. $N$ Eng $J$ Med. 2010;362(22):2053-2065.

60. Lambertini M, Campbell C, Bines J, et al. Adjuvant anti-HER2 therapy, treatment-induced amenorrhea (TIA) and survival in premenopausal patients (pts) with HER2-positive (HER2+) early breast cancer (EBC): analysis from the ALTTO trial (BIG 2-06) [abstract]. Ann Oncol. 2017;28(suppl):5.
61. Regan MM, Pagani O, Fleming GF, et al. Adjuvant treatment of premenopausal women with endocrine-responsive early breast cancer: design of the TEXT and SOFT trials. Breast. 2013;22(6):1094-1100.

62. Francis PA, Regan MM, Fleming GF, et al. Adjuvant ovarian suppression in premenopausal breast cancer. $N$ Engl J Med. 2015;372(5):436-446.

63. Pagani O, Regan MM, Walley BA, et al. Adjuvant exemestane with ovarian suppression in premenopausal breast cancer. $N$ Engl J Med. 2014;371(2):107-118.

64. Bernhard J, Luo W, Ribi K, et al. Adjuvant exemestane versus tamoxifen in premenopausal women with early breast cancer undergoing ovarian suppression: patients reported outcomes in the TEXT and SOFT randomised trials. Lancet Oncol. 2015;16(7):848-858.

65. Fleming G, Francis PA, Láng I et al: Randomized comparison of adjuvant tamoxifen (T) plus ovarian function suppression (OFS) versus tamoxifen in premenopausal women with hormone receptor-positive $(\mathrm{HR}+)$ early breast cancer (BC): update of the SOFT trial. Oral presentation at: 2017 San Antonio Breast Cancer Symposium; December 5-9; 2017; San Antonio, TX

66. Pagani O, Regan MM, Fleming GF et al. Randomized comparison of adjuvant aromatase inhibitor exemestane (E) plus ovarian function suppression (OFS) vs tamoxifen (T) plus OFS in premenopausal women with hormone receptor positive (HR+) early breast cancer (BC): update of the combined TEXT and SOFT trials. Oral presentation at: 2017 San Antonio Breast Cancer Symposium; December 5-9; 2017; San Antonio, TX.

67. Regan MM, Francis PA, Pagani O, et al. Absolute benefit of adjuvant endocrine therapies for premenopausal women with hormone receptorpositive, human epidermal growth factor receptor 2-negative early breast cancer: TEXT and SOFT trials. J Clinic Oncol. 2016;34(19):2221-2231.

68. Rossi E, Morabito A, De Maio E, et al. Endocrine effects of adjuvant letrozole+triptorelin compared with tamoxifen + triptorelin in premenopausal patients with early breast cancer. J Clin Oncol. 2008;26(2):264-270.

69. Breast International Group (BIG)1-98 Collaborative Group, Thürlimann B, Keshaviah A, et al. A comparison of letrozole and tamoxifen in postmenopausal women with early breast cancer. $N$ Engl $J$ Med. 2005;353(26):2747-2757.

70. Bellet M, Gray KP, Francis PA, et al. Twelve-month estrogen levels in premenopausal women with hormone receptor-positive breast cancer receiving adjuvant triptorelin plus exemestane or tamoxifen in the suppression of ovarian function trial (SOFT): the SOFT-EST substudy. [Abstract]. J Clin Oncol. 2016;34(14):1584-1593.

71. Del Mastro L, Boni L, Michelotti A, et al. Effect of the gonadotropinreleasing hormone analogue triptorelin on the occurence of chemotherapy-induced early menopause in premenopausal women with breast cancer: a randomized trial. JAMA. 2011;306(3):269-276.

72. Lambertini M, Boni L, Michelotti A, et al. Ovarian suppression with triptorelin during adjuvant breast cancer chemotherapy and long-term ovarian function, pregnancies, and disease-free survival: a randomized clinical trial. JAMA. 2015;314(24):2632-2640.

73. Moore HC, Unger JM, Philips KA, et al. Goserelin for ovarian protection during breast-cancer adjuvant chemotherapy. NEJM. 2015;372(10):923-932.

74. Buchholz S, Seitz S, Schally AV, et al. Triple-negative breast cancers express receptors for luteinizing hormone-releasing hormone (LHRH) and respond to LHRH antagonist cetrorelix with growth inhibition. Int J Oncol. 2009;35(4):789-796.

75. Schubert A, Hawighorst T, Emons G, Gründker C. Agonists and antagonists of GnRH-I and-II reduce metastasis formation by triple-negative human breast cancer cells in vivo. Breast Cancer Res Treat. 2011;130(3):783-790.

76. AIOM-AIRTUM Working Group. The number of Cancer in Italy $[I$ numeri del Cancro in Italia]. Il Pensiero Scientifico Editore, Rome 2016:75-82.

77. Stensheim H, Cvancarova M, Møller B, Fosså SD. Pregnancy after adolescent and adult cancer: a population-based matched cohort study. Int J Cancer. 2011;129(5):1225-1236. 
78. Letourneau JM, Smith JF, Ebbel EE, et al. Racial, socioeconomic, and demographic disparities in access to fertility preservation in young women diagnosed with cancer. Cancer. 2012;118(18):4579-4588.

79. Ruddy KJ, Gelber SI, Tamimi RM, et al. Prospective study of fertility concerns and preservation strategies in young women with breast cancer. J Clin Oncol. 2014;32(11):1151-1156.

80. Partridge AH, Gelber S, Peppercorn J, et al. Web-based survey of fertility issues in young women with breast cancer. J Clin Oncol. 2004;22(20):4174-4183.

81. Lee SJ, Schover LR, Partridge AH, et al. American Society of Clinical Oncology recommendations on fertility preservation in cancer patients. J Clin Oncol. 2006;24(18):2917-2931.

82. Lambertini M, Del Mastro L, Pescio MC, et al. Cancer and fertility preservation: international recommendations from an expert meeting. BMC Med. 2016;14(1):1.

83. National Comprehensive Cancer Network Clinical Practice Guidelines in Oncology. Breast Cancer. 2017. Available from https://www.nccn. org/store/login/login.aspx?ReturnURL=https://www.nccn.org/professionals/physician_gls/pdf/breast.pdf.

84. Peccatori FA, Azim HA Jr, Orecchia R, et al. Cancer, pregnancy and fertility: ESMO Clinical Practice Guidelines for diagnosis, treatment and follow-up. Ann Oncol. 2013;24(suppl 6):160-170.

85. Paluch-Shimon S, Pagani O, Partridge AH, et al. Second international consensus guidelines for breast cancer in young women (BCY2). Breast 2016;26:87-99.

86. Loren AW, Mangu PB, Beck LN, et al. Fertility preservation for patients with cancer: American Society of Clinical Oncology clinical practice guideline update. J Clin Oncol. 2013;31(19):2500-2510.

87. Italian Association of Medical Oncology (AIOM). Clinical Practice Guideline on Fertility Preservation in Cancer Patients; 2016. Available from http://www.aiom.it/professionisti/documenti-scientifici/lineeguida/2016_LGAIOM_Preserv_fertil.pdf.

88. Biglia N, Torrisi R, D’Alonzo M, Codacci Pisanelli G, Rota S, Peccatori FA. Attitudes on fertility issues in breast cancer patients: an Italian survey. Gynecol Endocrinol. 2015;31(6):458-464.

89. Moore HCF, Unger JM, Phillips K-A. Final analysis of SWOG S0230/ Prevention of early menopause study (POEMS). Poster presentation at: 2017 San Antonio Breast Cancer Symposium; December 5-9; 2017; San Antonio, TX.
90. Lambertini M, Ceppi M, Poggio F, et al. Ovarian suppression using luteinizing hormone releasing hormone agonists during chemotherapy to preserve ovarian function and fertility of breast cancer patients: a metaanalysis of randomized studies. Ann Oncol. 2015;26(12):2408-2419.

91. Coates AS, Winer EP, Goldhirsch A, et al. Tailoring therapies-improving the management of early breast cancer: St Gallen International Expert Consensus on the primary therapy of early breast cancer 2015. Ann Oncol. 2015;26(8):1533-1546.

92. Leonard RCF, Adamson DJA, Bertelli G, et al. GnRH agonist for protection against ovarian toxicity during chemotherapy for early breast cancer: the Anglo Celtic Group OPTION trial. Ann Oncol. 2017;28(8):1811-1816.

93. Gerber B, von Minckwitz G, Stehle H, et al. Effect of luteinizing hormone-releasing hormone agonist on ovarian function after modern adjuvant breast cancer chemotherapy: the GBG 37 ZORO study. J Clin Oncol. 2011;29:2334-2341.

94. Munster PN, Moore AP, Ismail-Khan R, et al. Randomized trial using gonadotropin-releasing hormone agonist triptorelin for the preservation of ovarian function during (neo)adjuvant chemotherapy for breast cancer. J Clin Oncol. 2012;30(5):533-538.

95. Lambertini M, Moore HCF, Leonard RCF et al. Pooled analysis of five randomized trials investigating temporary ovarian suppression with gonadotropin-releasing hormone analogs during chemotherapy as a strategy to preserve ovarian function and fertility in premenopausal early breast cancer patients [abstract]. San Antonio Breast Cancer Symposium; December 5-9, 2017; San Antonio, TX. Cancer Res. 2018;78(4 Suppl):abstract GS4-01.

96. Del Mastro L, Lambertini M. Gonadotropin releasing hormone ana$\operatorname{logs}$ for ovarian function protection during chemotherapy in young early breast cancer patients: the last piece of the puzzle? Ann Oncol. 2017;28(8):1683-1685.

97. Lambertini M, Boni L, Michelotti A, et al. Long-term outcome results of the phase III PROMISE-GIM6 study evaluating the role of LHRH analog (LHRHa) during chemotherapy (CT) as a strategy to reduce ovarian failure in early breast cancer (BC) patients [abstract]. J Clin Oncol. 2014;32(26):abstract105.

98. Elgindy EA, El-Haieg DO, Khorshid OM, et al. Gonadatrophin suppression to prevent chemotherapy-induced ovarian damage: a randomized controlled trial. Obstet Gynecol. 2013;121(1):78-86.
Breast Cancer - Targets and Therapy

\section{Publish your work in this journal}

Breast Cancer - Targets and Therapy is an international, peerreviewed open access journal focusing on breast cancer research, identification of therapeutic targets and the optimal use of preventative and integrated treatment interventions to achieve improved outcomes, enhanced survival and quality of life for the cancer patient

\section{Dovepress}

The manuscript management system is completely online and includes a very quick and fair peer-review system, which is all easy to use. Visit http://www.dovepress.com/testimonials.php to read real quotes from published authors. 